\title{
A practical methodology to assess corrosion in concrete sewer pipes
}

\author{
Shima Taheri ${ }^{1,2^{*}}$, Martin Ams ${ }^{1}$, Heriberto Bustamante ${ }^{3}$, Louisa Vorreiter $^{3}$, Michael Withford ${ }^{1}$, and Simon Martin Clark ${ }^{2}$ \\ ${ }^{1}$ Department of Physics and Astronomy, Macquarie University North Ryde, NSW 2109, Australia \\ ${ }^{2}$ Department of Earth and planetary Science, Macquarie University North Ryde, NSW 2109, Australia \\ ${ }^{3}$ Sydney Water, PO Box 399, Parramatta, NSW 2124, Australia
}

\begin{abstract}
The combination of Neutron Tomography (NT), Scanning Electron Microscopy (SEM, with and without elemental analysis), $\mathrm{pH}$ profiling and Microindentation Mapping techniques was used to develop a methodology for the assessment of concrete sewer pipe deterioration. We demonstrate a viable method for health monitoring of concrete sewer pipes and the evaluation of competing mitigation strategies.
\end{abstract}

\section{Introduction}

Monitoring and mitigation of corrosion in concrete sewer pipes is a significant cost to water utilities around the world amounting to millions of dollars per annum in Australia alone. Concrete corrosion is the principle factor affecting concrete sewer pipe longevity and reliability. This attack can happen both above and below the water line. The corrosion is predominantly caused by acid attack on the cement paste (CP) in the concrete.

Biogenic acid attack has been identified as the prominent concrete ailment in sewer which is accounted for almost $40 \%$ of the damage in concrete and brickwork sewers. This attack can happen both above and below the water line. Cement-based products, regardless of composition, have a poor resistance to solutions with a $\mathrm{pH}$ lower than 3 [1-4]. Two main approaches have been used to address this problem: reduction of the concentration of hydrogen sulfide $\left(\mathrm{H}_{2} \mathrm{~S}\right)$ in the sewer head space by either improved ventilation or additives (such as $\mathrm{FeCl}_{2}$ ) to the sewage and the application of surface treatments (such as linings or $\mathrm{Mg}(\mathrm{OH})_{2}$ ) to the sewer pipe to create a barrier [5-6].

One of the key objectives of Sydney Water's (SW) "Corrosion and Odour Strategy" is to minimize the production of chemical compounds, such as $\mathrm{H}_{2} \mathrm{~S}$ in the wastewater. The $\mathrm{H}_{2} \mathrm{~S}$ is transferred to the gas phase and to the overhead of the gravity sewers and is microbiologically oxidized to the strong corrodent sulfuric acid on the concrete above the water line. Addition of $\mathrm{FeCl}_{2}$ to the wastewater can minimize the $\mathrm{H}_{2} \mathrm{~S}$ thus minimizing sulfuric acid formation. Under these conditions, the corrosion of the concrete in gravity sewers is slowed down and can take several years to reach the stage where the physical integrity is compromised leading to potential collapse.

How effective these approaches are, has not been well documented with little quantitative data available in the literature. There is therefore the need to develop a methodology to monitor chemical changes in the concrete of the gravity sewers and correlate it with physical properties of the top surface of the concrete. Advances in tools and techniques for the characterization of multiphase systems such as concrete have opened up a new era for the diagnosis and treatment of structural deterioration and prevention of failure; e.g. in-situ assessment of deterioration using laser profilers [7].

Here we present a methodology that can be used to qualitatively and quantitatively measure concrete sewer pipe deterioration and determine the relative effectiveness of mitigation strategies by the combination of visual examination, Neutron Tomography (NT), Scanning Electron Microscopy (SEM), $\mathrm{pH}$ profiling and hardness measurements using micro-indentation.

\section{Experimental}

A set of concrete cores were recovered from a range of sewer environments in the Sydney sewage system. These consisted of samples from below flow, above flow and tidal regions of sewer pipes. The recovery sites were selected to include sections exposed to $\mathrm{FeCl}_{2}$ in the sewage, sections coated with $\mathrm{Mg}(\mathrm{OH})_{2}$ and sections with no treatment. The cores were sterilized using UV radiation to remove any biohazards prior to laboratory analysis. A summary of the characterization techniques used in this study is contained in Table 1 . The advantages and disadvantages of each technique are summarized in Table 2.

Direct visual examination showed that the surface of all cores, regardless of their location (roof, below flow or tidal area), were covered with a thin black film. The depth and pattern of corrosion (the visual color change and observed layered structured concrete) is not the same in the samples obtained from various regions.

\footnotetext{
* Corresponding author: shima.taheri@mq.edu.au
} 
Table 1. Overview of Characterization Techniques

\begin{tabular}{|c|c|c|}
\hline $\begin{array}{l}\text { Analytical } \\
\text { Technique }\end{array}$ & $\begin{array}{c}\text { Analytical } \\
\text { Purpose }\end{array}$ & $\begin{array}{c}\text { Conclusion from the } \\
\text { Results }\end{array}$ \\
\hline 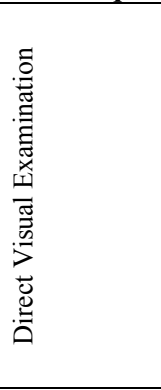 & $\begin{array}{l}\text { Quality } \\
\text { Control }\end{array}$ & $\begin{array}{l}\text { * General composition of } \\
\text { concrete and color } \\
\text { *Apparent coarse aggregate to } \\
\text { mortar proportions } \\
\text { *Depth of carbonation } \\
\text { *Nominal maximum size of } \\
\text { fine and course aggregates and } \\
\text { distribution in concrete. Particle } \\
\text { shape } \\
\text { * Crack depth, width } \\
\text { * Presence of pores or entrained } \\
\text { air }\end{array}$ \\
\hline 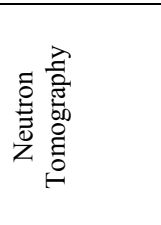 & $\begin{array}{c}\text { Three- } \\
\text { dimensional } \\
\text { structure }\end{array}$ & $\begin{array}{l}\text { *Assessment of defects and } \\
\text { depth of corrosion } \\
\text { * Determine the integrity of } \\
\text { structural components } \\
\text { * Multiple cracks detection } \\
\text { * Study hydrating cement } \\
\text { pastes }\end{array}$ \\
\hline 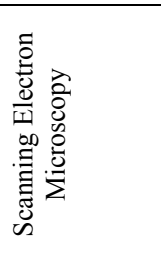 & $\begin{array}{l}\text { Structural } \\
\text { analysis }\end{array}$ & $\begin{array}{l}\text { *Studying the texture, } \\
\text { topography and surface feature } \\
\text { *Assessment of defects and } \\
\text { depth of corrosion } \\
\text { *Size and size distribution } \\
\text { * Shape } \\
\text { * Aggregation } \\
\text { * Dispersion }\end{array}$ \\
\hline 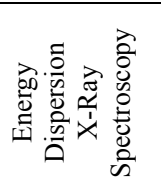 & $\begin{array}{l}\text { Elemental } \\
\text { analysis }\end{array}$ & $\begin{array}{l}\text { * Elemental analysis or } \\
\text { chemical characterization of a } \\
\text { sample } \\
\text { * Elemental mapping }\end{array}$ \\
\hline 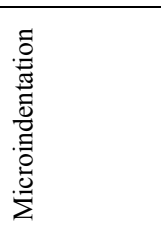 & $\begin{array}{c}\text { Hardness } \\
\text { determination }\end{array}$ & $\begin{array}{l}\text { *To determine the hardness of a } \\
\text { material to deformation } \\
\text { * Studying multiphase material } \\
\text { and determining case depth or } \\
\text { determining particle hardness. }\end{array}$ \\
\hline 递营 & $\begin{array}{l}\text { Chemical } \\
\text { state analysis }\end{array}$ & $\begin{array}{l}* \text { To determine the } \mathrm{pH} \text { of } \\
\text { cement paste at different depths } \\
\text { of a concrete core } \\
\text { *Visualization of the depth of } \\
\text { corrosion damage }\end{array}$ \\
\hline
\end{tabular}

Neutron tomography (NT) is a non-destructive method which we used to produce three dimensional images of the recovered cores revealing any cracks, voids and, more importantly, corroded layers without any artefacts that may be introduced during cutting and polishing. It is the neutron analogue of the CT-scan in a hospital in which a series of absorption images is taken while rotating a sample through $360^{\circ}$ and then combined to give a reconstructed three-dimensional image. NT is a valuable tool prior to SEM analysis to show if there are any changes in the concrete matrix or not, without sectioning the cores, however as mentioned in Table 2, it is expensive and not widely available. The spatial resolution of neutron tomography is also limited by the divergence of the neutron beam.

Figure 1 shows horizontal and vertical 3D reconstructed views of a representative core. Voids, cracks, size and shape of aggregates, areas of different density, intact and corroded zones are some information that can be extracted from 3D reconstruction of data.
Table 2. Strength and Limitation of Applied Techniques

\begin{tabular}{|c|c|c|}
\hline $\begin{array}{l}\text { Analytical } \\
\text { Technique }\end{array}$ & Strength & Limitation \\
\hline 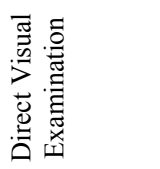 & $\begin{array}{l}\text { *Simple and Fast } \\
\text { * Inexpensive in } \\
\text { capital and labor } \\
\text { *Non-destructive }\end{array}$ & $\begin{array}{l}\text { * Imprecise } \\
\text { * The human element } \\
\text { * Misinterpretation }\end{array}$ \\
\hline 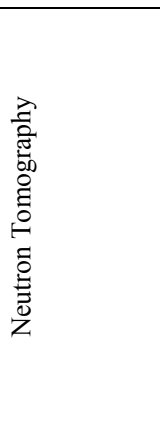 & $\begin{array}{l}\text { *Non-destructive } \\
\text { method } \\
\text { *Neutrons can image } \\
\text { the light elements and } \\
\text { pass through heavy } \\
\text { elements better than } \mathrm{x}- \\
\text { rays } \\
\text { *3D reconstruction } \\
\text { and visualization of } \\
\text { sample from 2D } \\
\text { neutron transmission } \\
\text { images taken from } \\
\text { different view angles }\end{array}$ & $\begin{array}{l}\text { * Extremely expensive } \\
* \text { The possibility that } \\
\text { the object might } \\
\text { become activated and } \\
\text { radioactive }\end{array}$ \\
\hline 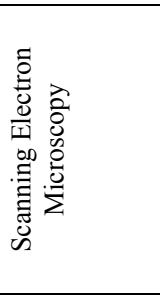 & $\begin{array}{l}\text { *High resolution } \\
\text { (down to sub- } \\
\text { nanometer) } \sim 10 \mathrm{~nm} \\
\text { *Direct measurement } \\
\text { of the size/size } \\
\text { distribution and shape }\end{array}$ & $\begin{array}{l}\text { *Conducting sample or } \\
\text { coating conductive } \\
\text { materials required } \\
\text { *Dry samples required } \\
\text { * Expensive } \\
\text { equipment } \\
\text { * Dimensions are } \\
\text { usually on the order of } \\
10 \mathrm{~cm}\end{array}$ \\
\hline 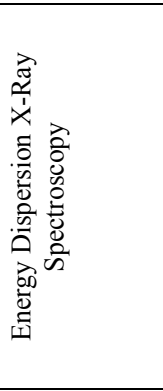 & $\begin{array}{l}\text { * Acquiring elemental } \\
\text { maps or spot chemical } \\
\text { analyses } \\
\text { *Rapid discrimination } \\
\text { of phases in } \\
\text { multiphase samples } \\
\text { * Discrimination of } \\
\text { phases based on mean } \\
\text { atomic number } \\
\text { *Compositional maps } \\
\text { based on differences in } \\
\text { trace element }\end{array}$ & $\begin{array}{l}\text { * Detection area is } \\
\text { limited by the field of } \\
\text { view of the SEM }\end{array}$ \\
\hline 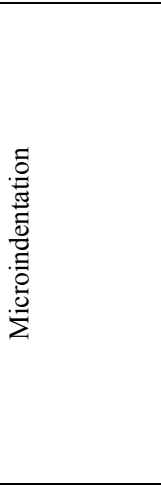 & $\begin{array}{l}\text { * Tests can be } \\
\text { conducted in a very } \\
\text { short time } \\
\text { * Indentation hardness } \\
\text { correlates roughly } \\
\text { linearly with tensile } \\
\text { strength } \\
\text { * The Vickers test has } \\
\text { a great advantage of } \\
\text { using one hardness } \\
\text { scale to test all } \\
\text { materials } \\
* \text { The ability to } \\
\text { monitor hardness as a } \\
\text { function of position }\end{array}$ & $\begin{array}{l}\text { * Since it is a contact } \\
\text { method it is considered } \\
\text { a destructive technique } \\
\text { on a micrometer scale }\end{array}$ \\
\hline 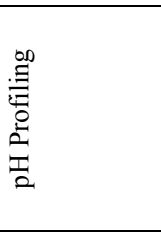 & $\begin{array}{l}* \text { Tests can be } \\
\text { conducted in a very } \\
\text { short time } \\
* \text { Very cost effective } \\
* \text { The ability to } \\
\text { monitor pH change as } \\
\text { a function of position }\end{array}$ & $\begin{array}{l}\text { * Inaccuracy due to } \\
\text { carbonation of the } \\
\text { exposed surface } \\
\text { * Variations in } \\
\text { precision due to human } \\
\text { error }\end{array}$ \\
\hline
\end{tabular}

Morphological differences are evident between the surface and sub-surface layers compared to the bulk. 


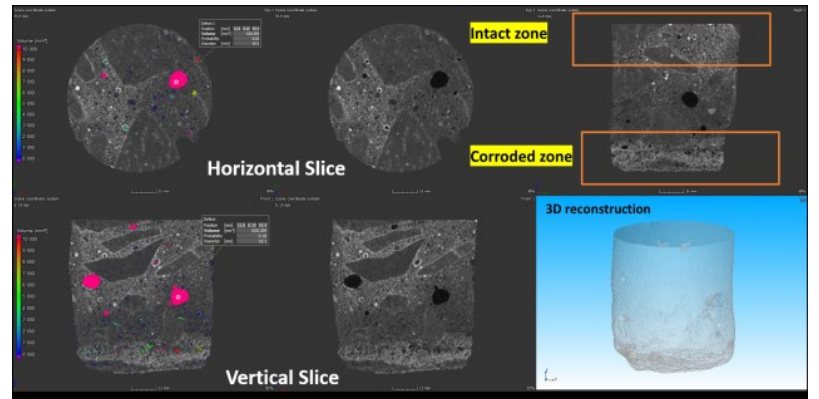

Fig. 1. Middle vertical and horizontal slices from reconstructed $3 \mathrm{D}$ datasets of cores.

Once we determined the extent of any damage and corrosion using NT we then cut and polished sections through the length of the cores (from the surface exposed to the sewage into the pipe) and used Scanning Electron Microscopy and Energy Dispersion X-Ray Spectroscopy (SEM+EDS) for a higher resolution examination of the structure of the core and to determine the distribution of elements within the core.

Figure 2 contains SEM images (high and low magnification) collected from the same core that is shown in Figure 1. The low magnification image on the left, is showing a highly deteriorated surface, followed by a transition to a fully intact concrete. A higher magnification image is best suited for examinations of microstructural features and as can be seen from the right SEM micrograph, crystals of gypsum, ettringite and voids are visible at the near surface area of that core $(0$ $100 \mu \mathrm{m}$ depth).

The elemental analysis (EDS) of the intact zone versus the surface concrete, shows that $\mathrm{Ca}$ in the surface of the core has been replaced by other elements such as $\mathrm{Mg}, \mathrm{Al}, \mathrm{S}, \mathrm{Fe}$. The intense presence of $\mathrm{Fe}$ in the first 500 $\mu \mathrm{m}$ of all specimens recovered from areas exposed to $\mathrm{FeCl}_{2}$ is also detectable.
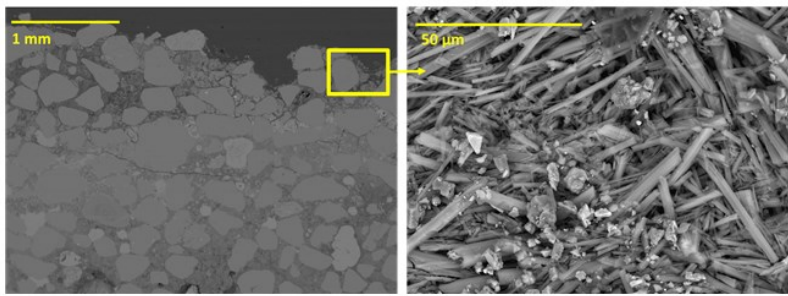

Fig. 2. SEM micrograph of concrete core surface at (left) low (scale bar: $1 \mathrm{~mm}$ ) and (right) high magnification (scale bar: 50 $\mu \mathrm{m})$

Microindentation hardness testing (or microhardness testing) is a method for measuring the hardness of a material on a microscopic scale. The indentations are made using a square-based pyramid indenter. The ratio of force to indentation area give a measure of hardness on the Vickers scale [9].

Figure 3 shows an example of a Vickers hardness measurement on one of our recovered cores. The typical square based pyramid indentation can be seen in the center of the image. The ideal surface finish is a highquality metallographic polish and sufficiently smooth and reflective to clearly resolve the microscopic hardness impression with the measuring microscope.

Due to the differences in core composition, treatment and age, the hardness of cores varies by quite an amount. The surface of all cores shows above $50 \%$ decrease in hardness compared to the intact concrete matrix.

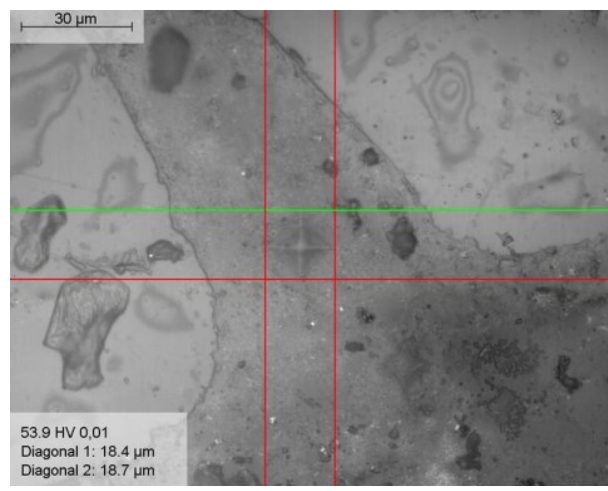

Fig. 3. A typical example of a Vickers hardness measurement on a polished concrete core using the micro-indenter with automated measurement of residual impression for pinpointing of the corners

pH Profiling is the use of $\mathrm{pH}$ indicators to determine the altered zones of cementitious materials [8]. Areas affected by acid corrosion can be easily visualized using few droplets of a universal $\mathrm{pH}$ indicator. This indicator can reveal acidic, neutral and alkaline $\mathrm{pH}$ areas with different color codes (Figure 4). For this test a smoothened and sanded concrete sample is required to minimize the effect of surface carbonation on $\mathrm{pH}$ reading. As can be seen in Figure 4 the exposed surface of the cores always has a lower $\mathrm{pH}$ (red/orange in color) presumably due to acid attack $(\mathrm{pH}<4)$. As the depth increases and the chance of chemical penetration decreases the $\mathrm{pH}$ increases above neutral. The intact concrete zone (uncorroded) has a $\mathrm{pH}$ above 11 as expected (purple in color).

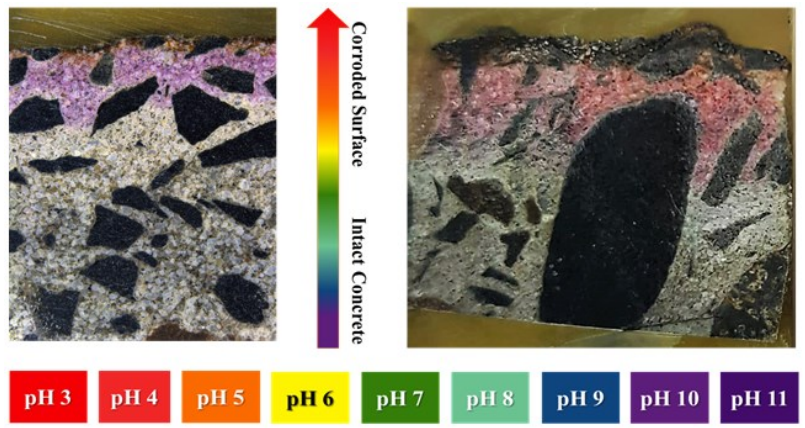

Fig. 4. An example of $\mathrm{pH}$ profiling of a concrete core: (right) under severe sulfuric acid attack and (left) under mild sulfuric acid attack

The combination of microindentation, $\mathrm{pH}$ profiling and SEM+EDS analysis reveals key information that can in principle correlates concrete softening with 2D mapping of elemental concentration. Figure 5 shows the correlation between calcium concentration, $\mathrm{pH}$ and hardness found in our study. 


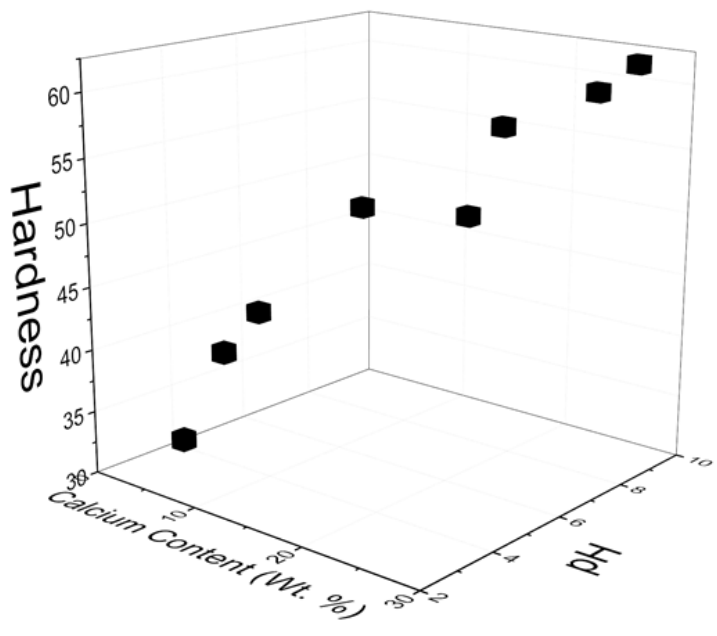

Fig. 5. Correlation between calcium concentration, $\mathrm{pH}$ and hardness.

All cores were found to have a gradient of properties. As we move away from the surface toward the bulk $\mathrm{pH}$, hardness and calcium concentration increase. The higher the $\mathrm{Ca}$ content the higher the $\mathrm{pH}$ and hardness of that section. In summary, we have shown that the combination of NT, SEM-EDS, $\mathrm{pH}$ profiling and hardness testing using micro-indentation can be used as an effective corrosion diagnostic technique. This methodology can give a good indication of the depth and severity of corrosion in a section of concrete sewer pipe and can be used as a health monitoring technique.

\section{Conclusion}

We have examined the deterioration of concrete cores subjected to sulfuric acid attack using our developed methodology. The quantitative and qualitative techniques used in this project each have their strengths and weaknesses, yet they can be extremely effective in combination with one another to assess chemical deterioration of concrete pipes. The recovered cores that we studied were found to have a range of different cement and concrete formulations. They had been exposed to different sewer environments and varied in age and the degree of deterioration of the examined concrete is greatly dependent on the exposure conditions. We found a depletion in $\mathrm{Ca}$ in all cores (treated and untreated) from the surface down to around 7-12 mm into the concrete. This correlates with changes in hardness and $\mathrm{pH}$.

From the limited cores tested in this project, we can conclude that cores dosed with $\mathrm{FeCl}_{2}$ or sprayed with $\mathrm{Mg}(\mathrm{OH})_{2}$ showed less Calcium depletion at depths above $6-8 \mathrm{~mm}$ and are successful in keeping the $\mathrm{pH}$ of intact $\mathrm{CP}$-zone of sewer concrete above neutral level compared to untreated samples. Cores from below flow areas are much softer compared to cores from tidal or roof areas and show greater (up to $12 \mathrm{~mm}$ ) depth of chemical penetration.
This work suggests that the periodical structural and mechanical core evaluation tests presented in this study could form a valuable part of asset management strategies in order to address maintenance challenges such as effectiveness and status of surface treatment of corrosion impacted pipes or sewage chemical dosing in the most efficient manner.

Due to variations in concrete composition, one treatment might not be suitable for every sewer pipe and the efficacy of a treatment should be examined prior to application using the above approach in order to determine the most effective form of treatment for that particular situation.

Neutron tomographic data were collected using the DINGO instrument in the Australian Centre for Neutron Scattering, operated by the "The Australian Nuclear Science and Technology Organisation", Lucas Heights, Australia. Thanks to Dr. Ulf Garbe for collecting the data and VGSTUDIO MAX technical consultants (Volume Graphics $\mathrm{GmbH}$ ) for assisting with the data processing and analysis. The SEM data were collected using a Hitachi Tabletop Microscope TM3030 and Zeiss EVO MA15. The hardness data were collected using "DuraScan" (Struers A/S) and Vickers HV 0.1 method. The authors would like to thank Sydney Water and Macquarie University for supporting this work through Enterprise Partnership Agreement MQ9201600357 and the OptoFab nod at Macquarie University.

\section{References}

1. E. Revertegat, C. Richet, P. Gegout, Cem. Concr. Res., 22, 259-272(1992).

2. H.T. Cao, L. Bucea, A. Ray, S. Yozghatlian, Cem. Concr. Compos., 19, 161-171(1997).

3. W.C. Panarese and Portland Cement Association, Environmental Performance of Concrete, ASM Handbook Volume 13B, Corrosion: Materials, $579-$ 588 (2005).

4. W. Kaempfer, and M. Berndt, Durability of Building Materials and Components, 1, 36-45 (1999).

5. N. Apté, 78th WIOA Victorian Water Industry Operations Conference \& Exhibition Bendigo Exhibition Centre (2015).

6. S. LeCount, 24th No-Dig International Conference and Exhibition: No-Dig Down Under Brisbane, Australia, (2006).

7. N. Stanić, F. H. Clemens, and J. G. Langeveld, J. Hydraul. Eng. 143, 2 , 04016079 (2016).

8. S. Igarashi, A. Bentur, and S. Mindess, Adv. Cem. Based Mater., 4, 48-57 (1996).

9. S. Manso, and A. Aguado, Mater. Constr., 67, 108 (2017). 